Olga Mitrenina

Saint Petersburg State University Saint Petersburg State University of Aerospace Instrumentation

Saint Petersburg, Russia mitrenina@gmail.com

\title{
THE CORPORA OF OLD AND MIDDLE RUSSIAN TEXTS AS AN ADVANCED TOOL FOR EXPLORING AN EXTINGUISHED LANGUAGE
}

This review takes a close look at the corpora of Old and Middle Russian. A linguistic corpus is a collection of machine-readable texts with specific types of annotations and advanced search possibilities.

The main advantage of corpora is that linguistic annotation (or tagging) is attached to every word or element of the designated texts; this allows one to search not only for certain word forms but also for different linguistic data. The most common annotation is lexical: the basic form (lemma), grammatical and semantic information can be attached to every word. The annotations can also include morphological tagging, syntactic tagging (parsing) that reflects the relationships between words in every sentence, phonetic and prosodic tagging, and other types of annotation. It can be prepared automatically or manually. The latter is much more time-consuming, although it allows one to avoid the errors of automatic tagging.

Search options in a corpus can be varied, but basically they allow one to search for words based on grammatical and other annotated information. In addition, the search options usually allow for specifying the distance between words in a query.

We will consider five main corpora of Old and Middle Russian texts. ${ }^{1}$

(1) These corpora are listed in М. В. КОПОтЕв, Введение в корпусную хингвистику [M. V. KоРОтеV, Introduction to Corpus Linguistics], Helsinki, 2014 [Electronic textbook]. 


\section{RUSSIAN NATIONAL CORPUS}

The Russian National Corpus (http://ruscorpora.ru/en/) is the primary and the largest corpus of Russian; it includes over 300 million words. It is being developed by a large group of linguists and programmers under the direction of the Institute of Russian Language of the Russian Academy of Sciences.

The historical subcorpus of the Russian National Corpus consists of four parts: Church-Slavonic, Middle Russian, Old Russian, and Birchbark corpora. The interface for those corpora is in Russian only, but it is similar to the interface in English developed for Modern Russian texts (http://ruscorpora.ru/en/search-main.html).

a) the Church-Slavonic corpus (http://ruscorpora.ru/search-orthlib. html) represents the East Slavonic izvod (recension) of the Church Slavonic language in its archaic, standard, and modern forms. This corpora includes 1254 documents, 304089 sentences, and 4700406 words. Most of the texts are liturgical. The user can select a subcorpus by choosing the titles, the date ranges, and the genre of the text and by specifying translated or original texts. ${ }^{2}$

b) the Middle Russian corpus (http://ruscorpora.ru/search-mid_ rus.html) includes texts from the 14th century to the beginning of the 18th century. It includes 1969 documents, 141098 sentences, and 3106219 words. One can select a subcorpus by choosing the titles, the authors, the date ranges, and the genre of the text and by language style (common, official, etc).

c) the Old Russian corpus (http://ruscorpora.ru/search-old_rus. html) includes 14 documents with 92170 sentences and 443461 words. These are original Old Russian texts (all of the Old Russian chronicles and the writings of Kirill of Tura) and a number of translated texts, including the Old Bulgarian Izbornik (1076). The subcorpus can be created only by choosing certain documents. By clicking certain translated words in a search result you can see their Greek originals and their location in the original text.

(2) For an example of a study of the translated Old Russian texts using this corpus, see A. А. ПичхАДЗЕ, “Корпус древнерусских переводов XIXII вв. и изучение переводной книжности Древней Руси" [А. А. РІсНKHADZE, "The Corpus of the Old Russian Translations of the Eleventh and Twelfth Centuries and Studies of the Old Russian Literature of Translation"], in: Национальный корпус русского языка: 2003-2005, Москва, 2005, с. 251262. 
d) the Birchbark corpus (http://ruscorpora.ru/search-birchbark. html) includes 885 documents, 3716 sentences, and 19461 words. It contains all the known Russian birchbark documents that have readable text. It was formed on the basis of the Old Russian Birchbark Documents project (http://gramoty.ru/), which includes not only texts but also pictures and non-readable fragments. Users can select a subcorpus by choosing the city, the genre, language type, and the date ranges of the text. By clicking the title of the document in the search results, one can see details of the birchbark documents and a link to an image.

The Church-Slavonic, Old Russian, and Birchbark corpora allow lexical and grammatical searches that can take into account the distance between searched words or grammatical forms. The Middle Russian corpus allows only an exact search for a certain word or phrase. The Church-Slavonic, Old Russian, and Birchbark corpora have a virtual keyboard that allows inputting of old Cyrillic letters, and three types of orthography are available. All four corpora are currently being expanded, so they will definitely include more documents than listed here. In addition, a syntactic search is being developed for the historical subcorpus of the Russian National Corpus, but it is not yet available for users.

\section{REgENSBURG RUSSIAN DIACHRONIC CORPUS}

The Regensburg Russian Diachronic Corpus (RRuDi) was created at the Faculty of Slavic Languages of the University of Regensburg; it was developed further as the database for the project Corpus Linguistics and Diachronic Syntax, supported by the German Research Foundation in cooperation with Humbold University in Berlin. ${ }^{3}$

It consists of two parts: an old version and a new version. The old version (http://www-korpus.uni-regensburg.de/diakorp/) includes 11 texts in Old and Middle Russian. It allows one to search for exact word forms and to use the symbol _ as a shorthand for "any single character" and the symbol \% as a shorthand for "any characters" in search strings. You may also choose between display using orthographically normalized ("rendered") forms or in a display that is close to the original form.

(3) Some features of this corpus are described in R. MEYER, "The Regensburg Diachronic Corpus of Russian," in: Proceedings of the Conference "Corpora-2006," St. Petersburg, 2006. 
For proper rendering of characters the user should install a Unicode font containing the full Cyrillic glyph range. Most of the characters will also be displayed properly in ArialUnicodeMS or even in Times New Roman. But unfortunately no virtual keyboard is available in RRuDi to enter Slavonic letters.

The new version (http://rhssl1.uni-regensburg.de/SlavKo/korpus/ rrudi-new) includes more than 100000 words. It consists of the following texts: the works of Kirill of Tura, Domostroj, Xoždenie Bogorodicy po mukam (Apocalypse of the Virgin), Povest' vremennych let (Primary Chronicle), January menaion, and the Novgorod Chronicle. All these texts have morphosyntactic tagging that allows one to search in specified texts for words in certain grammatical forms and in certain syntactic relationships. This is the only corpus that allows syntactic searches for Old Russian texts.

The searching form incudes a complicated query builder with some instructions in English. To search for word forms, the user selects a corpus and enters a search string between double quotation marks, e.g.: “быхъ." One can also use regular expressions, which must be surrounded by slashes ( / ) instead of quotation marks: /[Бб]ыхъ/. Annotations may be searched for using an annotation name and value or with regular expressions. For example, the query for datives will look like this: tag=/. ${ }^{*}$ Dat. ${ }^{*} /$, but unfortunately there is no user-friendly list of annotation values in the system at present, although the developers are planning to add one.

The user can access the Query Builder and Annis Query Language Tutorial that are integrated into the system, but they will not provide simple explanations, so it is better just to e-mail the administrators of the corpus, who will provide instructions on an individual basis.

\section{CORPUS OF THE VELIKIE MINEI ČET'I}

The Corpus of the Velikie Minei Čet'i (http://www.vmc.uni-freiburg. de) was developed at the Department for Slavonic Studies at the University of Freiburg, Germany. This is an electronic corpus of the parts of the greatest Church Slavonic menology, which was compiled by Macarius, Metropolitan of Moscow and his scribes in the $16^{\text {th }}$ century. ${ }^{4}$ The corpus contains the Acts of the Apostles with patristic com-

(4) For the principles of this corpus, see A. RABUS, S. SAVIĆ, R. WALDENFELS, "Towards an electronic corpus of the Velikie Minei Čet'i," in: Пpeоткриване: Супрасълски сборник, старобългарски паметник от $\mathrm{X}$ век 
mentaries, Pauline epistles, and the Ecumenical letters, all of which relate to the 30th of June. It includes more than 292000 words.

The corpus has no grammatical annotation so it does not allow searches for grammatical forms. But it does have three types of lexical searches. The simple search is for exact words or phrases. The advanced search allows one to look for two words specifying the distance between them; "begins with," "ends with," and "case sensitive" options are available. The complex search can be performed using the CQP syntax and special characters that are listed in the help window on the search panel.

The corpus has two convenient features:

(1) Server-sided web fonts: The user does not need to have to have Old Cyrillic fonts installed in order to have the corpus displayed correctly because the font is installed on the server. Consequently, the corpus is available on post-PC devices such as iPads or handsets.

(2) On-the-fly suggestions: When the user enters letters into the search field, the corpus will show all words starting with this string.

A virtual keyboard is available to enter Slavonic letters and superscript characters. The interface of this corpus is in English.

Search results are presented in a context of about a dozen of words; this is usually enough for linguistic study but not sufficient for a historical study. Unfortunately the name of the document is not listed in the search results; the user can see only the original number of the searched word or phrase along with the page number, column number, and line number in the original text.

\section{4. “MANUSCRIPT" PROJECT}

The "Manuscript" corpus (http://www.manuscripts.ru/index_en.html) was created at the Laboratory of Computer-aided Philological Research at Udmurtia State University, Russia. ${ }^{5}$ It is formed by electronic copies of Old and Middle Russian manuscripts, including docu-

[Rediscovery: Bulgarian Codex Suprasliensis of 10th century], Sofia, 2012, c. 343-353.

(5) A brief description of this corpus is available at V. BARANOV, A. VOTINTSEV, R. GNUTIKOV, A. MirONOV, S. OSHCHEPKOV, V. ROMANENKO, “Old Slavic Manuscript Heritage: Electronic Publications and Full-Text Databases," in: EVA 2004 London (Electronic Imaging, the Visual Arts Conference \& Beyond) conference Proceedings, London, 2004, 11.1-11.8. 
ments in the Glagolitic alphabet. The corpus includes about 3.5 million words.

The full version of every Cyrillic document is available with the possibility of switching the alphabet to Latin (in three different systems of representation), to Modern Russian, and to other alphabets so that the user can simplify the search by various means. The interface is in English and search forms are available for the entire text or for a selected document. An advanced search through the entire collection can be performed using the advanced search form (http://www. manuscripts.ru/mns/srch.simple?p_lang=EN). Unfortunately, help files are available only in Russian and advanced search forms are complicated and unclear. The corpus allows searches for grammatical forms in the specified documents, although grammatical tags are available only in Russia.

A word index, inverted word index, and quantitative word index are available for most of the documents.

\section{5. “CORPUS OF NORTHERN RUSSIAN HAGIOGRAPHICAL TEXTS"}

The Corpus of Northern Russian Hagiographical Texts "SCAT" (http://project.phil.spbu.ru/scat/) is being created by the Department of Mathematical Linguistics ${ }^{6}$ at the Philological Faculty of St.-Petersburg State University, where the author works as an associate professor. This corpus includes an electronic version of Northern Russian hagiographical texts with a total of 200000 words. Some texts are available in PDF format.

The interface is in Russian only, and searches by word or by part of the word are available (http://project.phil.spbu.ru/scat/search.php). The developers are planning to add grammatical and syntactic annotation to some of the texts in this corpus, which will allow the user to search for words with certain grammatical features.

(6) For the basic ideas of this corpus, see A. С. ГЕРД, Е. $\Lambda$. АЛЕКСЕЕВА, И. В. АЗАРОВА, $\Lambda$. А. ЗАХАРОВА, “Электронный корпус текстов по памятникам древнерусской агиографической литературы" [A. S. GERD, E. L. Alexeeva, I. V. AZAROVA, L. A. ZAKHAROVA, "Electronic corpus of Old Russian hagiographic texts"], Научно-техническая информация, сер. 2, вып. 9, Москва, 2004, с. 16-20. 
The corpora reviewed here can be helpful tools for historians and philosophers who work with Old and Middle Russian texts, especially after their further development and refinement. 